\title{
Pengaruh Implementasi Pendekatan Kontruktivisme Model Needham Terhadap Hasil Belajar Ditinjau dari Kemampuan Komunikasi Matematis
}

\author{
Agus Purnomo ${ }^{1}$, Maylita Hasyim ${ }^{2 *}$ \\ ${ }^{1,2}$ Program Studi Pendidikan Matematika, STKIP PGRI Tulungagung, \\ Jl. Mayor Sujadi Timur No. 7 Plosokandang, Tulungagung 66221, Indonesia. \\ *Email: maylita@stkippgritulungagung.ac.id, Telp.+6285330688556
}

Article received : 01-06-2018, article revised : 12-02-2019, article published: 31-03-2019

DOI : $10.25273 /$ jipm.v7i2.2577

\begin{abstract}
Abstrak
Penelitian ini bertujuan untuk menganalisis: (1) pengaruh pendekatan Kontruktivisme model Needham terhadap hasil belajar matematika; (2) pengaruh kemampuan komunikasi matematis siswa terhadap hasil belajar matematika; dan (3) pengaruh implementasi pendekatan Kontruktivisme model Needham terhadap hasil belajar matematika ditinjau dari kemampuan komunikasi matematis. Pendekatan dalam penelitian ini adalah kuantitatif dengan menggunakan rancangan penelitian eksperimen dan jenis penelitian kausal komparatif. Teknik pengambilan sampel dengan cluster sampling, dengan sampel siswa kelas X TBS 2 sebagai kelas eksperimen dan kelas TBG 1 sebagai kelas kontrol SMK Negeri 1 Pogalan Trenggalek. Teknik pengumpulan data yaitu tes kemampuan komunikasi matematis dan tes hasil belajar matematika. Pengujian hipotesis menggunakan teknik analisis variansi dua jalur sel tak sama dengan taraf signifikansi 5\%. Hasil analisis analisis variansi dua jalur sel tak sama menunjukan bahwa: (1) ada pengaruh yang signifikan antara pendekatan Kontruktivisme model Needham terhadap hasil belajar matematika; (2) ada pengaruh yang signifikan antara kemampuan komunikasi matematis terhadap hasil belajar matematika; dan (3) tidak ada pengaruh interaksi yang signifikan antara pendekatan Kontruktivisme model Needham dan kemampuan komunikasi matematis terhadap hasil belajar matematika.
\end{abstract}

Kata Kunci: Hasil Belajar Matematika; Kemampuan Komunikasi Matematis; Pendekatan Kontruktivisme Model Needham; Trigonometri.

\section{The Influence of Implementation of Constructivism Approach Model Needham to Learning Outcomes Viewed from Mathematical Communication Skill}

\section{Abstract}

This study aims to analyze whether: (1) the influence of the approach of contracting the needham model to the mathematics learning outcomes; (2) the influence of students' mathematical communication ability on the mathematics learning outcomes; and (3) the influence of the implementation of the needham's approach to the learning outcomes in terms of communication skills mathematical. This research uses a quantitative approach with experimental design and causal comparative research. Sampling technique with cluster sampling, with a sample of students from class X TBS 2 as an experimental class and class 1 TBG as a control class at SMK Negeri 1 Pogalan Trenggalek. Data collection techniques are mathematical communication ability test and learning outcomes test. Hypothesis testing using anava technique of two cell lines is not equal to $5 \%$ significance level. Prior to hypothesis test, prerequisite test was done by equilibrium test with $\mathrm{t}$ test of two independent samples, normality test with kolmogorov-smirnov test and homogeneity test with $f$ test. The result of anava technique of two cell lines is not equal shows that: (1) there is influence of the approach of contracting of Needham model to the result of learning mathematics: (2) there is influence of mathematical communication ability to the learning result of mathematics: (3) no interaction's influence of the approach of contracting of Needham model to the result of mathematics learning in terms of mathematical communication.

Keywords: Learning Outcomes; Mathematical Communication Ability; The Needham Constructivism Approach; Trigonometry. 


\section{PENDAHULUAN}

Dewasa ini paradigma pendidikan telah bergeser dari paradigma behavioristik menuju kontruktivisme. Pada dasarnya pendekatan kontruktivisme menekankan proses membangun sendiri konsep-konsep yang dipelajari oleh siswa (student oriented) (Wonoraharjo, 2006, seperti dikutip Utami, M.Iskandar, \& Ibnu, 2009). Pandangan kontruktivistik meyakini bahwa siswa merespon pengalaman-pengalaman pancaindera dengan mengkontruksikan suatu skema atau struktur kognitif ke otak. Pengetahuan atau pengertian siswa diperoleh sebagai akibat dari proses konstruksi (aktif) yang berlangsung terus menerus dengan cara mengatur, menyusun dan menata ulang pengalaman yang dikaitkan dengan struktur kognitif yang telah dimiliki sehingga struktur kognitif tersebut sedikit demi sedikit dimodifikasi dan dikembangkan (Utami et al., 2009).

Berdasarkan paham kontruktivisme, dalam proses belajar mengajar guru tidak serta merta memindahkan pengetahuan kepada siswa dalam bentuk yang serba sempurna. Dengan kata lain, siswa harus membangun suatu pengetahuan itu berdasarkan pengalamannya masing-masing. Hamzah dan Muhlisrarini (2014) menyatakan pembelajaran adalah hasil dari usaha siswa itu sendiri dan guru tidak boleh belajar untuk peserta didik. Pendekatan kontruktivistik bertolak dari fokus apa yang telah diketahui pembelajar tentang alam sekitarnya. Mempergunakan hal ini sebagai dasar pendidikan mengembangkan metodemetode pembelajaran untuk membantu para pembelajar mendidik diri mereka sendiri mengenai alam disekitarnya. Hasil akhirnya adalah para pembelajar bukan saja menguasai fakta-fakta ilmiah tetapi juga memiliki cara berfikir analitis yang dapat mereka terapkan pada berbagai situasi dalam hidup mereka (Iskandar, 2004 dalam Utami et al., 2009).

Needham (Nair, 2005 seperti dikutip Aulia, 2015) merupakan salah satu tokoh yang menerapkan kontruktivisme ke dalam pembelajaran sains di sekolah. Penelitian yang dilakukan menghasilkan tahap-tahap belajar sebagai berikut: Orientasi; Pencetusan ide; Penstrukturan semula ide; Penggunaan ide; Refleksi.

Seperti yang telah disampaikan di atas dalam tahapan-tahapan belajar menurut Needham bahwa kemampuan komunikasi siswa dapat membantu siswa melakukan modifikasi atau penyusunan idea-idea secara berurutan. Kemampuan komunikasi matematis menunjang kemampuankemampuan matematis lainya, misalnya kemampuan pemecahan masalah. Dengan kemampuan komunikasi yang baik maka suatu masalah akan lebih cepat bisa direpresentasikan dengan benar dan hal ini akan mendukung untuk penyelesaian masalah.

Berdasarkan uraian latar belakang di atas maka penelitian ini bertujuan untuk: 1) menganalisis ada atau tidaknya pengaruh secara signifikan implementasi pendekatan kontruktivisme model needham terhadap hasil belajar matematika materi trigonometri pada siswa SMK Negeri 1 Pogalan tahun pelajaran 2017/2018; 2) menganalisis ada atau tidaknya pengaruh secara signifikan kemampuan komunikasi matematis terhadap hasil belajar matematika materi trigonometri dari pada siswa SMK Negeri 1 Pogalan tahun pelajaran 2017/2018; 3) menganalisis ada atau tidaknya pengaruh interaksi secara signifikan implementasi pendekatan kontruktivisme model needham terhadap hasil belajar matematika materi trigonometri 
ditinjau dari kemampuan komunikasi matematis pada siswa SMK Negeri 1 Pogalan tahun pelajaran 2017/2018.

\section{METODE}

\section{Jenis dan Rancangan Penelitian}

Pendekatan penelitian ini adalah kuantitatif dengan jenis penelitian kausal komparatif dan rancangan eksperimen. Adapun rancangan penelitian ini sebagai berikut:

$\begin{array}{llll}\text { Kelas Eksperimen } & : \mathrm{R} & \mathrm{X} & \mathrm{O}_{2} \\ \text { Kelas kontrol } & : \mathrm{R} & & \mathrm{O}_{4}\end{array}$

Dalam desain ini terdapat dua kelompok yang masing-masing dipilih secara random (R). Kelompok pertama diberi perlakuan (X) dan kelompok yang lainnya tidak. Kelompok yang diberi perlakuan disebut kelompok eksperimen dan kelompok yang tidak diberi perlakuan disebut kelompok kontrol. Pengaruh adanya perlakuan (treatment) adalah $\left(\mathrm{O}_{2}: \mathrm{O}_{4}\right)$ (Sugiyono, 2012).

\section{Populasi, Sampel, dan Teknik Peng- ambilan Sampel}

Penelitian ini dilakukan di SMK Negeri 1 Pogalan Kabupaten Trenggalek. Populasi dalam penelitian ini adalah seluruh siswa kelas $\mathrm{X}$ dengan sampel penelitian terdiri dari dua kelas, satu kelas sebagai kelas eksperimen dan kelas lainya sebagai kelas kontrol. Pengambilan sampel menggunakan teknik cluster sampling pada penelitian ini dilaku-kan dengan mengambil secara acak kelas dengan cara pengundian. Pengundian ini dilakukan dengan menuliskan di kertas undian nama seluruh kelas populasi. Dengan pengundian tadi maka terpilihlah dua kelas yang menjadi sampel penelitian ini, yaitu kelas X TBS 2 sebagai kelas eksperimen dan kelas TBG 1 sebagai kelas kontrol.
Selanjutnya kedua kelas sampel tersebut dilakukan uji kesetimbangan dengan uji $t$ dua sampel independen untuk mengetahui apakah kemampuan kedua sampel tersebut dalam keadaan seimbang.

\section{Teknik Analisis Data}

Pengumpulan data yang digunakan dalam penelitian ini adalah dengan menggunakan dokumentasi nilai ulangan harian terakhir kelas sampel, instrumen tes kemampuan komunikasi matematis dan tes hasil belajar matematika. Teknis analisis data dalam penelitian ini meliputi:

1. Uji keseimbangan bertujuan untuk mengetahui kemampuan kelas sampel dalam keadaan seimbang sehingga kelas dapat dijadikan sampel. Uji Kesetimbangan dalam penelitian ini menggunakan uji $t$ dua sampel independen.

2. Uji normalitas dilakukan untuk mengetahui apakah sampel penelitian ini berdistribusi normal. Uji kesetimbangan dalam penelitian ini menggunakan uji kolmogorov-smirnov.

3. Uji homogenitas digunakan untuk mengetahui apakah beberapa varian populasi adalah sama atau tidak Uji homogenitas dalam penelitian ini menggunakan dengan uji F.

4. Uji hipotesis dalam penelitian ini menggunakan analisis variansi 2 jalan sel tak sama dan hasil dari analisi data menunjukan bahwa $\mathrm{H}_{0 \mathrm{~B}}$ ditolak; sehingga perlu dicari signifikan uji rataan dengan uji komparasi ganda atau uji lanjut pasca anava.

\section{Hipotesis Penelitian}

Hipotesis dalam penelitian ini adalah:

(a) $\mathrm{H}_{0 \mathrm{~A}}: \mu_{1}=\mu_{2}$

(Tidak ada pengaruh pendekatan Kontruktivisme model Needham terhadap hasil belajar matematika materi trigonometri pada siswa 
SMK Negeri 1 Pogalan tahun pelajaran 2017/2018)

$$
\mathrm{H}_{1 \mathrm{~A}}: \mu_{1} \neq \mu_{2}
$$

(Ada pengaruh pendekatan Kontruktivisme model Needham terhadap hasil belajar matematika materi trigonometri pada siswa SMK Negeri 1 Pogalan tahun pelajaran 2017/2018)

(b) $\mathrm{H}_{0 \mathrm{~B}}: \mu_{1}=\mu_{2}=\mu_{3}$

(Tidak ada pengaruh komunikasi matematis terhadap hasil belajar matematika materi trigonometri pada siswa SMK Negeri 1 Pogalan tahun pelajaran 2017/2018)

$\mathrm{H}_{1 \mathrm{~B}}$ : paling tidak ada dua rerata yang tidak sama.

(Ada pengaruh komunikasi matematis terhadap hasil belajar matematika materi trigonometri pada siswa SMK Negeri 1 Pogalan tahun pelajaran 2017/2018)

(c) $\mathrm{H}_{0 \mathrm{AB}}:(\alpha \beta)_{i j}=0$ untuk setiap $\mathrm{i}=1,2$ dan setiap $\mathrm{j}=1,2 \ldots \mathrm{p}$ dan $\mathrm{j}=$ $1,2 \ldots, \mathrm{q}$

(Tidak ada pengaruh pendekatan Kontruktivisme model Needham terhadap hasil belajar matematika materi trigonometri ditinjau dari komunikasi matematis pada siswa SMK Negeri 1 Pogalan tahun pelajaran 2017/2018)

$\mathrm{H}_{1 \mathrm{AB}}$ : paling sedikit ada satu $(\alpha \beta)_{i j}$ yang tidak nol

(Ada pengaruh pendekatan Kontruktivisme model Needham terhadap hasil belajar matematika materi trigonometri ditinjau dari komunikasi matematis pada siswa SMK Negeri 1 Pogalan tahun pelajaran 2017/2018)

\section{HASIL DAN PEMBAHASAN}

\section{Hasil Penelitian}

Rata-rata nilai kemampuan komunikasi matematis siswa pada masing-masing kategori dapat dilihat pada Tabel 1 berikut:

Tabel 1. Rata-rata Tes Hasil Belajar Matematika

\begin{tabular}{|c|c|c|c|c|}
\hline \multirow{2}{*}{$\begin{array}{c}\text { Model } \\
\text { Pembela } \\
\text { jaran }\end{array}$} & \multicolumn{3}{|c|}{$\begin{array}{c}\text { Kriteria Kemampuan } \\
\text { Komunikasi }\end{array}$} & \multirow{2}{*}{$\begin{array}{c}\text { Rataaan } \\
\text { Margin } \\
\text { al }\end{array}$} \\
\hline & Tinggi & Sedang & Rendah & \\
\hline Needham & 100 & 83,7 & 63,33 & 82,34 \\
\hline $\begin{array}{l}\text { Konvensi } \\
\text { onal }\end{array}$ & 93,75 & 74,04 & 58,33 & 75,37 \\
\hline
\end{tabular}

Uji hipotesis dalam penelitian ini menggunakan anova dua jalan sel tak sama. Hasil perhitungan dapat dilihat dalam Tabel 2 berikut:

Tabel 2. Hasil Uji Anava Dua Jalan Sel Tak Sama Dependent Variable: Tes Hasil Belajar

\begin{tabular}{lrc}
\hline \multicolumn{1}{c}{ Source } & F & Sig. \\
\hline Corrected Model & 31,404 & 0,000 \\
\hline Intercept & 4538,058 & 0,000 \\
\hline Model_Pembelajaran & 8,861 & 0,004 \\
\hline Kemampuan_Komunikasi & 62,218 & 0,000 \\
\hline $\begin{array}{l}\text { Model_Pembelajaran * } \\
\text { Kemampuan_Komunikasi }\end{array}$ & 0,685 & 0,508 \\
\hline
\end{tabular}

\section{Uji Hipotesis 1}

Hasil dari perhitungan anava dua jalan sel tak sama adalah $\boldsymbol{F}_{\text {hitumg }}=\mathbf{8 , 8 6 1}$, karena $\quad F_{\text {hitumg }}=8,861>F_{\text {tabel }}=4,00$ maka $\mathrm{H}_{0 \mathrm{~A}}$ ditolak. Hasil pengujian tersebut membuktikan bahwa terdapat perbedaan yang signifikan terhadap hasil belajar antara pembelajaran Kontruktivisme model Needham dan pembelajaran Konvensional. Berdasarkan rata-rata tes hasil belajar yang diperoleh siswa dengan pembelajaran Kontruktivisme model Needham dan pembelajaran Konvensional berturut-turut 82,34 dan 75,37. Hal ini membuktikan bahwa rata-rata nilai tes hasil belajar siswa yang diperoleh pembelajaran Kontruktivisme model Needham lebih tinggi dari pada hasil belajar pembelajaran Konvensional. 


\section{Uji Hipotesis 2}

Hasil perhitungan analisis varians dua jalan sel tak sama pada Tabel 2 diperoleh $F_{\text {hitumg }}=62,218$, Hal ini menunjukkan bahwa $\quad F_{\text {hitumg }}=8,861>F_{\text {tabel }}=3,15$ mengakibatkan ditolaknya $\mathrm{H}_{0 \mathrm{~B}}$. Hal ini menunjukkan ada pengaruh komunikasi matematis terhadap hasil belajar matematika. Berdasarkan kesimpulan tersebut sehingga perlu dicari signifikan uji rataan dengan uji komparasi ganda atau uji lanjut pasca anava.

\section{Uji Hipotesis 3}

Berdasarkan hasil analisis varians dua jalan sel tak sama pada Tabel 2. mengenai hasil belajar siswa antara model pembelajaran dan kemampuan komunikasi diperoleh
$F_{\text {hitumg }}=0,685$, hal ini berarti bahwa

$F_{\text {hitumg }}=0,685<F_{\text {tabel }}=3,15$ mengakibatkan diterimanya $\mathrm{H}_{0 \mathrm{AB}}$. Hal ini menunjukkan tidak adanya interaksi antara model pembelajaran dan kemampuan komunikasi matematis terhadap hasil belajar matematika.

\section{Uji Komparasi Ganda}

Berdasarkan kesimpulan analisis variansi dua jalan dengan ukuran sel tak sama diatas menunjukan bahwa $\mathrm{H}_{0 \mathrm{~B}}$ ditolak; sehingga perlu dicari signifikan uji rataan dengan uji komparasi ganda atau uji lanjut pasca anava. Teknik yang digunakan dalam uji komparasi ganda adalah dengan metode Scheffe'.

Tabel 3. Hasil Uji Komparasi Ganda Menggunakan Metode Scheffe'

\begin{tabular}{llcrc}
\hline $\begin{array}{c}\text { (I) Kemampu- } \\
\text { an_Komunikasi }\end{array}$ & \multicolumn{1}{c}{$\begin{array}{c}\text { (J) Kemampu- } \\
\text { an_Komunikasi }\end{array}$} & $\begin{array}{c}\text { Mean Difference } \\
(\mathbf{I}-J)\end{array}$ & $\begin{array}{c}\text { Std. } \\
\text { Error }\end{array}$ & Sig. \\
\hline \multirow{2}{*}{ Tinggi } & Sedang & $17,26^{*}$ & 2,775 & 0,000 \\
\cline { 2 - 5 } & Rendah & $35,23^{*}$ & 3,256 & 0,000 \\
\hline \multirow{2}{*}{ Sedang } & Tinggi & $-17,26^{*}$ & 2,775 & 0,000 \\
\cline { 2 - 5 } & Rendah & $17,97^{*}$ & 2,140 & 0,000 \\
\hline Rendah & Tinggi & $-35,23^{*}$ & 3,256 & 0,000 \\
\hline & Sedang & $-17,97^{*}$ & 2,140 & 0,000 \\
\hline
\end{tabular}

a) Uji Komparasi antara kemampuan komunikasi tinggi dengan sedang

Berdasarkan hasil analisis pada Tabel 3 mengenai uji pasca anava kemampuan komunikasi matematis diperoleh nilai signifikansi $0,000<\alpha=0,05$ mengakibatkan ditolaknya $\mathrm{H}_{0}$. Hal ini menunjukkan ada perbedaan hasil belajar yang signifikan antara kemampuan komunikasi matematis tinggi dengan kemampuan komunikasi matematis sedang.

b) Uji Komparasi antara kemampuan komunikasi sedang dengan rendah Berdasarkan hasil analisis pada Tabel 3 mengenai uji pasca anava kemampuan komunikasi matematis diperoleh nilai signifikansi $0,000<\alpha=0,05$ mengakibatkan ditolaknya $\mathrm{H}_{0}$. Hal ini menunjukkan ada perbedaan yang signifikasi hasil belajar antara kemampuan komunikasi matematis sedang dengan kemampuan komunikasi matematis rendah.

c) Uji Komparasi antara kemampuan komunikasi tinggi dengan rendah

Berdasarkan hasil analisis pada Tabel 3 mengenai uji pasca anava kemampuan komunikasi matematis diperoleh nilai signifikansi $0,000<\alpha=0,05$ mengakibatkan ditolaknya $\mathrm{H}_{0}$. Hal ini menunjukkan ada perbedaan yang signifikasi hasil belajar 
antara kemampuan komunikasi matematis tinggi dengan kemampuan komunikasi matematis rendah.

\section{Pembahasan}

Sebagaimana telah dijelaskan sebelumnya, bahwa sebelum data dilakukan pengujian hipotesis, terlebih dahulu data harus memenuhi uji prasyarat yaitu uji normalitas, uji homogenitas dan uji kesetimbangan. Jika pengujian prasyarat telah terpenuhi, maka uji hipotesis dapat dilakukan. Berdasarkan perhitungan uji normalitas dengan taraf signifikan 5\% maka diperoleh harga $\chi_{\text {hitung }}^{2}=0,113$ untuk kelas eksperimen $\operatorname{dan} \chi_{\text {hitung }}^{2}=0,156$ untuk kelas kontrol, sedangkan $\chi_{\text {tabel }}^{2}=0,160$. Karena $\chi_{\text {hitung }}^{2} \notin \mathrm{DK}$ sehingga dapat disimpulkan bahwa populasi berdistribusi normal.

Untuk perhitungan uji homogenitas diperoleh hasil pengujian yaitu nilai sig. lebih besar dari 0,05 artinya data berasal dari kelompok yang memiliki varians homogen. Karena hasil pengujian menggunakan SPSS menunjukan hasil nilai sig. $=0,443$ dan lebih besar dari 0,05 maka dapat disimpulkan bahwa kedua kelas tersebut homogen.

Selanjutnya hasil uji keseimbangan dilakukan dengan menggunakan uji- $t$ dua sampel independen, dari hasil analisis dapat disimpulkan bahwa data tersebut memiliki kesetimbangan karena memiliki nilai Sig.(2-tailed) > $0,05 \quad$ atau $t_{\text {hitung }}=-0,24<t_{\text {tabel }}=1,997$, sehingga dapat disimpulkan bahwa kedua kelas tersebut memiliki kemampuan yang seimbang. Dengan demikian uji prasyarat terpenuhi, sehingga uji hipotesis dapat dilakukan.

Hipotesis ditolak jika memiliki nilai $F_{\text {hitung }}>F_{\text {tabel }}$ dan diterima jika memiliki nilai $F_{\text {hitung }}<F_{\text {tabel }}$. Berdasarkan analisis data hasil belajar matematika siswa didapatkan untuk uji hipotesis (1) dan (2) bahwa $F_{\text {hitung }}>F_{\text {tabel }} \quad$ sehingga hipotesis penelitian ini ditolak, dan untuk uji hipotesis (3) didapat $F_{\text {hitung }}<F_{\text {tabel }}$ sehingga hipotesis ini diterima. Dengan demikian dilakukan uji pasca anava dengan metode Scheffe' dengan hasil:

1. Kemampuan komunikasi matematis siswa yang tinggi lebih baik dibandingkan dengan kemampuan komunikasi matematis siswa yang sedang;

2. Kemampuan komunikasi matematis siswa yang tinggi lebih baik dibandingkan dengan kemampuan komunikasi matematis siswa yang rendah;

3. Kemampuan komunikasi matematis siswa yang sedang lebih baik dibandingkan dengan kemampuan komunikasi matematis siswa yang rendah.

Berdasarkan hasil penelitian dan analisis data menggunakan program SPSS versi 21, diperoleh hasil sebagai berikut:

1. Ada pengaruh pendekatan Kontruktivisme model Needham terhadap hasil belajar matematika materi trigonometri pada siswa SMK Negeri 1 Pogalan tahun pelajaran 2017/2018. Dalam penelitian terdahulu yang dilakukan oleh Nia Gardenia (2016) dengan hasil pembelajaran kontruktivisme model Needham berpengaruh terhadap hasil belajar. Peneliti lainnya yaitu Eprita Suani (2013) UIN Suska Riau yang menyimpulkan berdasarkan penelitiannya bahwa pendekatan konstruktivisme model Needham dalam pembelajaran matematika berpengaruh positif terhadap hasil belajar matematika. Berdasarkan dari beberapa penelitian tersebut menguatkan bahwa pendekatan Kontruktivisme 
model Needham mempengaruhi hasil belajar matematika.

2. Ada pengaruh kemampuan komunikasi matematis terhadap hasil belajar matematika materi trigonometri pada siswa SMK Negeri 1 Pogalan tahun pelajaran 2017/2018. Dalam penelitian terdahulu yang dilakukan oleh Afiani (2016) didapatkan kesimpulan bahwa terdapat pengaruh kemampuan komunikasi matematis siswa terhadap prestasi belajar siswa MTs Darussalam. Berdasarkan dari penelitian tersebut menguatkan bahwa kemampuan komunikasi matematis mempengaruhi hasil belajar matematika.

3. Tidak ada pengaruh pendekatan Kontruktivisme model Needham terhadap hasil belajar matematika materi trigonometri ditinjau dari komunikasi matematis pada siswa SMK Negeri 1 Pogalan tahun pelajaran 2017/2018. Hal ini karena tidak ada interaksi antara kemampuan komunikasi $\left(\mathrm{X}_{2}\right)$ dengan model pembelajaran $\left(\mathrm{X}_{1}\right)$ dalam memberikan efek terhadap hasil belajar matematika (Y), artinya kedua variabel ini berdiri sendiri dalam memepengaruhi hasil belajar (Y). Kemungkinan-kemungkinan yang mempengaruhi hasil penelitian ini sehingga menunjukan tidak adanya pengaruh signifikan dikarenakan adanya faktor-faktor yang mempengaruhi hasil belajar. Hasil belajar yang dicapai siswa dipengaruhi oleh dua faktor, yaitu faktor internal yang berasal dari siswa tersebut dan faktor eksternal yang berasal dari luar siswa (Sudjana, 2000).

\section{DAFTAR PUSTAKA}

Baharudin, \& Wahyuni, E. N. (2015). Teori Belajar \& Pembelajaran. (A. Sava, Ed.) (1 ed.). Yogyakarta: Arus Media. Budiyono. (2004). Statistika Untuk Penelitian. (Suyono, Ed.) (1 ed.). Surakarta: Sebelas Maret University press.
Jadi dapat disimpulkan bahwa berdasarkan dari penelitian yang pernah dilakukan sebelumnya tersebut dapat diketahui bahwa pembelajaran kontruktivisme model Needham pada pembelajaran matematika dan kemampuan komunikasi matematis dapat meningkatkan hasil belajar. Maka dalam hal ini semakin mendukung penelitian ini bahwa pembelajaran kontruktivisme model Needham dapat untuk meningkatkan hasil belajar matematis pada siswa SMK Negeri 1 Pogalan.

\section{SIMPULAN}

Berdasarkan hasil analisis data dan pembahasan, maka diambil beberapa kesimpulan bahwa : 1) Ada pengaruh yang signifikan pendekatan Kontruktivisme model Needham terhadap hasil belajar matematika materi trigonometri pada siswa SMK Negeri 1 Pogalan tahun pelajaran 2017/2018; 2) Ada pengaruh yang signifikan kemampuan komunikasi matematis terhadap hasil belajar matematika materi trigonometri pada siswa SMK Negeri 1 Pogalan tahun pelajaran 2017/2018; dan 3) Tidak ada pengaruh yang signifikan pendekatan Kontruktivisme model Needham terhadap hasil belajar matematika materi trigonometri ditinjau dari komunikasi matematis pada siswa SMK Negeri 1 Pogalan tahun pelajaran $2017 / 2018$.

Hamzah, A., \& Muhlisrarini. (2014). Perencanaan Dan Strategi Pembelajaran matematika (1 ed.). jakarta: Rajawali Pers.

Onong Uchjana, E. (2009). Ilmu Komunikasi Teori dan Praktik. Bandung: PT 
JIPM (Jurnal Ilmiah Pendidikan Matematika), 7(2), Maret 2019- 139

Agus Purnomo, Maylita Hasyim

Remaja Rosdakarya Offset.

Purwanto. (2010). EVALUASI HASIL

BELAJAR. (B. Santosa, Ed.). Yogyakarta: PUSTAKA BELAJAR.

Sugiyono. (2012). Metode Penelitian

Kuantitatif \& Kualitatif Dan $R \& D$.

Bandung: Alfabeta.

Sumarmo. (2003). Pembelajaran matematika untuk Mendukung pelaksanaan Kurikulum

Berbasis Kompetnsi. Bandung.

Thobroni, M., \& Mustofa. (2013). Belajar

dan Pembelajaran: Pengembangan
Wacana dan Praktik Pembelajaran dalam Pembangunan Nasional. Yogyakarta: Ar-Ruzz Media.

Utami, B., M.Iskandar, S., \& Ibnu, S. (2009). Penerapan Pembelajaran Kontruktivisme Dalam Pembelajaran Kimia Di SMU. Prosiding Seminar Nasional Kimia dan Pendidikan Kimia 2009, 198-208. 